\title{
Chapter 21 \\ Steppe and Sown: Eurasianism, Soil \\ and the Mapping of Bukhara in the Light of Soviet Ethnographic Accounts
}

\author{
Susanne Marten-Finnis
}

\begin{abstract}
This chapter reveals how ecological zones and their division into steppe and sown, nomadic and sedentary people, helped Russian ethnographers to understand the heritage and urban neighbourhood principles of Bukhara. It charts the launch and significance of ethnographic enquiry into this former oasis city within the context of Eurasianism, and illuminates the notion of soil in Russian thought, together with the central role it played in the study of the interrelationship between environmental factors and socio-cultural changes. The evidence will be used to present ethnographic accounts as a way of transferring knowledge between Asia and Europe, and argue in favour of a flexible approach negotiating between nature and culture, and as a process of hybridization, whereby cultures come together and, by learning from each other, create a pathway towards Eurasian integration and global intellectual interaction.
\end{abstract}

Keywords Eurasianism $\cdot$ Notion of soil $\cdot$ Mapping Bukhara

Ethnographic accounts $\cdot$ Sukhareva $\cdot$ Heritage $\cdot$ Cosmopolitan citizenship

Knowledge transfer between Asia and Europe

\subsection{Introduction}

A few years ago, the Silk Road concept was rejuvenated by the Central Asian states, notably Kazakhstan, and Belarus, when they formulated plans for a regional economic partnership with Russia, which led to the foundation of the Eurasian Economic Union. Those countries possess three precious things: space, geographical proximity to economic centres-Europe, China and the Arabian Gulf-and vast reserves of energy and other natural resources that their neighbouring markets-Europe to the west and China to the east - are keen to share. These are highly motivating factors for the promotion of knowledge transfer between Asia and Europe.

S. Marten-Finnis $(\bowtie)$

School of Languages and Applied Linguistics, University of Portsmouth, Portsmouth, UK e-mail: Susanne.Marten-finnis@ port.ac.uk

L. E. Yang et al. (eds.), Socio-Environmental Dynamics along the Historical Silk Road, https://doi.org/10.1007/978-3-030-00728-7_21 
Underpinning their moves towards Eurasian integration is the concept of 'Eurasianism', a school of thought arguing that Russia is uniquely qualified to bridge the gap between Asia and Europe, Orient and Occident. Eurasianism built a case for the geographical unity of Russia-Eurasia, drawing on evidence from research into ecological zones grouped into the four geographical categories tundra, forest, steppe and dessert.

Today, the renewed discussion of Eurasian integration provides us with the opportunity to revisit the school of Eurasianism and, along with it, some aspects that deserve further scholarly attention, namely the embedding of these geographical categories within the Europe-Russia-Asia juxtaposition and the impact they had on socio-cultural change.

These are the strands of this chapter, which in its first part, will shed light on Eurasianism as a school of thought, and the legacy of Russian Orientalist scholarship among Soviet-trained ethnographers. Significant in the present context is their concept of mapping a new area on the basis of the four ecological zones tundra, forest, steppe and dessert, in particular the division into steppe and sown, nomadic and sedentary societies. What is the relevance of this concept for the study of the interrelationship between environmental factors and social change? And what role might it play in today's renewed discussion on Eurasian integration?

These questions will be discussed on the basis of original ethnographic accounts on Bukhara assembled during the years 1948 to 1976, and on the basis of the earliest reported observations indicating the Russian interest in this former oasis city, published by Russian civil servants and government emissaries in memoranda, brochures and periodicals. Drawing upon this rich and long-neglected body of knowledge, the second part will highlight the role of Bukhara in the historical Silk Road and in modernizing Imperial Russia. This will be a point of departure to elucidate, in the third part, the pioneering contribution of Soviet-trained ethnographers, of Olga Sukhareva in particular, and their systematic enquiry into the "mores of the land" [нравы земли]. This is a key concept in Russian ethnographic enquiry, which means the study of cultural and behavioural habits, normally pertaining not just to a place or region and its inhabitants, but also to a particular era, i.e. comprising geography, history and sociology - heterogeneous fields of research to cross both the humanities and social sciences. In today's research landscape, it might be at home under the umbrella of Area Studies.

The aim of this chapter is to demonstrate how this concept helped to understand Bukhara's neighbourhood principles and heritage, and how the city positioned itself between steppe and sown, human development and environment. The evidence will be used to present ethnographic accounts as a way of transferring knowledge between Asia and Europe, and argue in favour of a flexible approach negotiating between nature and culture, and as a process of hybridization, whereby cultures come together and, by learning from each other, create a pathway towards global intellectual interaction. 


\subsubsection{Eurasianism Versus Europeanism: The Notion of Soil in Russian Thought}

Ethnographic expeditions enjoyed government patronage in both Imperial and Soviet Russia. Their reports were a valuable source of knowledge about the empire's remote areas and its population. Their importance thus increased in the aftermath of imperial expansion in the last third of the nineteenth century, as the knowledge they mined helped to administer the newly acquired lands, the Caucasus, Central Asia and the Middle Volga region: a huge oriental space that Russia needed to reconcile with the cultural historical space the Russian nation had called its own to date (Bassin 1991). One way of coping with this task was to collect data about these lands and its subjects, almost entirely Muslims, mapping the area and completing fragmentary charts by way of ethnographic enquiry.

Russian politicians and intellectuals agreed that, as a civilized empire, Russia had the duty to unravel the complex and poorly understood customs of its subjects in order to grasp their ways of life and beliefs. As a result, the role of ethnographers, linguists and geographers rose to prominence during the Era of the Great Reforms initiated under the reign of Tsar Alexander II (1855-1881). During this period, ethnography turned out to be the principal science in the Russian Modernization project of Turkistan.

A few years ago, the Silk Road concept was rejuvenated and led to the foundation of the Eurasian Economic Union, and suddenly the concepts of Russian Orientalist scholars, specifically those of ethnographers, were back in focus (Kamp 2010; Stronski 2011; Tolz 2011; Huhn 2016; Sartori 2016). Of particular relevance in this respect is their view that Russia formed a continental bridge between Asia and Europe. This significance of soil in Russian thought goes back to the concept that the earth's land surface is divided into discrete territorial massifs, which originated with ancient Greek geographers who first identified the three continents of Europe, Asia and Africa as natural geographical entities (Bassin 1991).

As cartographic accuracy improved, more and more interpretations of geographical space were articulated in Russia. Among the variety of contrasting geopolitical self-images Russia invented for herself as a particular geographical entity stretching between Asia and Europe, the notion of soil kept its relevance. This was in contrast to Europe whose geographical realm since the fourteenth century was increasingly identified with the spirituality of Christendom, and a civilization whose ideologies claimed cultural and political exclusiveness and, ultimately, superiority (Bassin 1991).

\subsubsection{The Scythian Theme}

The notion of soil and the understanding of Russia as a land-based empire bridging the two continental entities, Asia and Europe, with no major body of water separating them-is central to the concept of Eurasianism. While pre-Petrine Russia remained 
largely untouched by the dogma of European superiority, the reign of Tsar Peter the Great saw the emergence of two rather contradictory viewpoints. On the one hand, Peter acknowledged an orientation towards European values and the unconditional pre-eminence of European civilization. On the other hand, the expeditions he sent out to southern Siberia in order to explore the area in search of natural resources and new trade routes, unearthed the existence of the Scythians, a pastoral people who populated the grassy steppe of Eurasia over 2500 years ago. The discovery of their lifestyle in the 1720 s, and the more accurate maps led to greater interest in the geography and history of the peoples populating Russia-Eurasia and subsequently, to a new identity framework. With the exploration of the vast region stretching between northern China and the Black Sea, the identification with the Scythians and the idea of Russia-Eurasia as a third continent, entered Russian consciousness. As a result, modernizing Imperial Russia saw an increasing number of intellectuals looking to Asia rather than Europe, for self-identification.

As a School of thought, however, Eurasianism was formally established only in 1921 by Russian emigrants in Berlin, i.e. outside Russia, yet as an identity framework foreseen to include the entirety of Russian society (Riasanovsky 1967). The verve of Eurasianism displayed the profile of its founders' professional expertise ${ }^{1}$ (Savitsky et al. 1921). In their manifesto, they created an original interaction between geopolitics, economy, philosophy and history, and generated a positive discourse about the Orient. Based on the argument that Russia was closer to Asia than to Europe, Eurasianists advocated a concept that saw the economic future of Russia in the comprehension of its continental nature and in the appreciation to this nature with all its regional variety and considerable natural resources, rather than in what they called "the aping of the oceanic policy of the western colonial powers" (Laruelle 2007). It was the enormous Eurasian plain stretching between the two continents that qualified Russia to bridge the gap between Orient and Occident, they argued. In their view, the decisive significance of Russia's ethnic and cultural complexity lay not in the interaction between nations, but between steppe and forest societies inhabiting Russia-Eurasia, and thus in the major and organic contribution of the eastern peoples to Russian culture (Halperin 1983).

This attitude, prevalent in Russian thought long before the formation of Eurasianism in 1921, had also influenced the approach of Russian scholars to study Orientalism, i.e. its individual aspects, its aesthetic assumptions, religious quests, intellectual priorities and political entanglements and their interrelationships. Their contribution will be considered here in the light of what they shared with the Eurasianists, rather than in the light of debates surrounding the contribution of Russian Orientalist scholars to the historiography of Central Asia, or their position within the wider field of power in Imperial or Soviet Russia.

With the Eurasianists, Russian Orientalist scholars shared two things: the positive discourse about the Orient and the supremacy of geographical over ideological space,

\footnotetext{
${ }^{1}$ The economist N. S. Savitsky (1895-1968), the ethnographer and linguist N. S. Trubetskoi (1890-1938), the musicologist and art critic P. P. Suvchinsky (1892-1985), and the historian and theologian G. V. Florovsky (1893-1979).
} 
i.e. understanding socio-cultural changes while prioritizing territorial and environmental factors over ideology. The significance of this approach to mapping a new area increased as early as following the competition for supremacy in Central Asia between the British and the Russians, known as "The Great Game", and the subsequent Russian advance into the territories of the ancient Silk Road in the 1860s.

\subsubsection{The Legacy of Russian Orientalist Scholarship: A Transcultural Perspective}

Not surprisingly, the decades to come saw the rise of Oriental Studies in Russian Universities. First influenced by the impact of nationalism on European scholarship, Russian Orientalists, in particular those of the Rozen School, ${ }^{2}$ eventually turned from their western orientation and developed their own approach to reconciling national aspirations and imperial governance within the Russian context, rather than reproducing the agenda of their Western European peers (Tolz 2011, 13-19). This is all the more remarkable as none of the Rozen disciples was ethnic Russian; and it was perhaps this very condition that enabled them to look at the oriental heritage of Russia's new subject nationalities with a transcultural perspective.

These scholars argued in favour of forging a multi-ethnic community (Jersild 1997, 101; Yaroshevski 1997, 61, 65-72), based on the principles of civic nationalism in the sense of social integration and shared political values and responsibilities among Russians and non-Russians despite linguistic, cultural and religious differences. Their pathway to citizen-building foresaw cultural and political integration through educational projects shared with the subject nationalities in the eastern and southern borderlands, with the aim of fostering among the country's entire population a sense of community and unity. This was to be achieved through political and spiritual fusion built on common, state-derived (Russian) civic norms and shared between Russians and indigenous people (Tolz 2011, 13-19).

Not only did their recommendation differ from the ways of national community building pursued by the maritime powers Britain and France, whose remote Muslim lands could be reached only by sea. It also articulated a pathway towards integrating ethnic minorities with their emerging nationalisms, into the imperial structures that would have a significant impact on Soviet nationalities policies during the 1920s (Hirsch 2005).

The educational projects scholars put forward entailed a regulated transfer of knowledge that was based on teaching the native population in textbooks specifically developed in their own languages, about their local histories and heritage. This way, they claimed, the latter would first develop an ethno-cultural awareness of their own

\footnotetext{
${ }^{2}$ Referring to the disciples of Viktor Romanivich Rozen (1864-1908), Professor of Arabic at the Faculty of Oriental Languages at St. Petersburg University: they include Vasilii V. Barthold (1869-1930), Nikolai Ia. Marr (1864-1934), Sergei F. Oldenburg (1863-1934) and Fedor I. Shcherbatskoi (1866-1942).
} 
fatherlands [маленкая родина], which would eventually bring them closer to the Russian motherland [большая родина]. In other words, minorities were not simply absorbed into the Russian Empire, but become more knowledgeable of their own histories and heritage. An appreciation of their own ethno-cultural particularities would raise the awareness of their heritage and subsequently foster awareness and loyalty to all-Russian concerns bringing them into a better position to contribute to pan-Russian activities.

However, Eurasianism, as an alternative to Bolshevik rule, did not leave the realms of Russian Emigration; and the concepts of citizen-building advocated by Russian pre-revolutionary Orientalist scholars were largely neglected by tsarist politicians. Nevertheless, the notion of soil and the positive discourse they had created about the Orient, in particular their recommendations about furthering Eurasian integration by transferring knowledge via ethnographic enquiry, was put into practice by their Soviet successors (Tolz 2011, 3). Under Soviet conditions, their pathway to citizenbuilding, foresaw the training of indigenous people for information, administration and ethnographic research in order to learn about Russia's remote periphery, and adapt government instructions and services to local culture, with the overall aim to facilitate integration rather than breed separation. A consequence of this policy, was the initiation, as early as in 1918, of the Turkestan Institute of Oriental Studies, intended to bring scholars from Russia's European centre to Central Asia in order to train experts of heritage, history and languages from among the indigenous population. In order to facilitate this policy, the Department of Practice (практический omde $\Omega$ ) was established in 1923 (Biulleten Sredne-Aziatskogo Gosudarstvennogo Universiteta 1924; Sirazhdinov 1970).

\subsubsection{The Steppe and Sown Dichotomy}

Another concept that remained popular among those who studied the social history of Central Asia referred to the symbiotic relationship between the steppe and the sown-between the domestic lifestyle of the settled people in the oasis cities and the nomadic lifestyle in areas where severer climatic conditions made civilization more fragile.

According to this concept, Central Asian history is defined largely by the dynamics of nomadic-sedentary relations often hostile, even violent, but always mutually interdependent (Foltz 1999, 23-24). Pastoral peoples would provide raw materials, e.g. wool or leather from the steppes, to be processed by the technologies of the oasis-dwellers, who would offer manufactured goods in return. On a different level, nomads would often attack and plunder the settled folk. They might then either withdraw to the steppes or, seduced by civilisation, remain and become assimilated (Grousset 1970).

From this outset, Tsarist administrators in Turkestan had established that religious ritual manifested itself mainly through the rituals of everyday life among the settled people, which was why Islam had gained a firmer stance in the Central Asian cities 
than among the nomads of the steppe region. In their view, townspeople therefore required more attention, as their fervent piety was linked to the backwardness and isolation of Central Asia, to which Russian social policies had to bring modernity by strengthening secular practices and eliminating undesirable manifestations of religious fanaticism (Brower 1997).

Another motivation for the division of ethnographic enquiry into steppe and sown was the fact that it corresponded to peoples' self-perception even until after the Bolsheviks had launched the process of citizen-building. When ethnographers started to affix to the people of Turkistan and the steppe national labels such as Kazakh, Kirgiz or Uzbek, people were hesitant to apply them to themselves. While the nomadic element was exclusively Turkic being made up of Kazakhs, Turkmens and to a minor extent Kirgiz, the sedentary peoples included both Iranian (Tajiks) and Turkic (Uzbeks, Karakalpaks etc.) elements. Yet, individuals would tend to think of themselves as members of a (nomadic) tribe or a (city) clan rather than as belonging to a whole people (Schuyler 1966, XIII-XIV). Questioned about their national affiliation many Bukharans would respond that they "used to be Tajiks but now they had become Uzbek", with further variations between female and male parts of a family, and a tendency of the former to see themselves as Tadjik, and the latter feeling predominantly Uzbek (Sukhareva 1966, 122).

It was on this basis - citizen-building, indigenization and prioritization of urban over rural studies - that the Bolshevik government launched the programme of ethnographic enquiry into the inner structure of Bukhara's residential neighbourhoods, their workforce, social composition and ethnogenesis (Sukhareva 1966, 21). In the process of working towards this target, however, it turned out that the division into steppe and sown could not be maintained and the study of the region's rural settlements (Sovremennyi kishlak 1926) was prioritized over the study of urban neighbourhoods (Sukhareva 1966, 15).

Only in 1948, the leading Soviet Orientalist scholar Ilia P. Petrushevskii, at the time heading the Oriental Department of the University of Leningrad, recorded that despite long-lasting efforts, the historical study of the Central Asian city was one of the thinnest chapters in Russian Orientalist historiography (Petrushevskii 1948, 85). The history of Bukhara in particular had been grossly neglected, he argued, and its recording was by then overdue. According to Petrushevskii, the mapping of Bukhara would need to embrace the city's historical topography at the crossroad of ancient trade routes and the impact of population influx on the ethnic composition of this diverse urban community and the variety of goods they produced. Such an approach, he suggested, should then be a point of departure for a close examination of individual neighbourhoods, the professional realms of their residents, their interaction, heritage and religious rituals (Petrushevskii 1948, 85).

It is with a view to this heritage and the entanglements between steppe and sown, ethnogenesis and occupation, that the mapping of Bukhara will be discussed in the second part of this chapter. The particular role Bukhara occupied in the Soviet construction of ethno-national territories and identities, and the politics and historiography of Islam in the region (Khalid 2007, 2015) will not be considered here. 


\subsection{Mapping Bukhara}

Along with Petrushevskii's plea came the proposal to widen the scope of research and study the rise of the city in all its facets, including its heritage: its material culture, local artisanship and preserved customs on the basis of testimonies and personal accounts (Jakobovsky 1951, 3-4). It was recommended that, due to the dearth of written records, interviews with Bukhara's residents should be conducted by Soviettrained, indigenous scholars of ethnography whose command of local languages and customs would qualify them as the best protagonists of a knowledge transfer from their native homelands, to the centre in Moscow (Barthold 1927; Shishkin 1936, 1943; Umniakov 1923).

Reports on testimonies and personal encounters could be the result of short-term assignments commissioned to government emissaries, in which case they would take the form of well-qualified memoranda. They could also appear as a piece of scholarly work that relied on systematic academic enquiry, assembled over an extended period of time by scholars who reviewed a city's history, geography, ethnography and sociology. The latter are under scrutiny here. Composed by Soviet-guided indigenous ethnographers, many of them female, they reflect the privileged access they were granted to the city's individual neighbourhoods, in particular the inner courtyards, which were exclusively the domain of women. Their meticulously logged reports are the topic of this subchapter, which will introduce the launch and significance of Soviet ethnographic enquiry into Bukhara, discuss its prior observations, and provide a periodization.

\subsubsection{The Role of Bukhara in the Historical Silk Road: A Network Topology}

What was it that attracted Soviet ethnographers to Bukhara in particular? Tracing the links to its past was the best way, Soviet ethnographers argued, to understand the structure of the oriental city, its neighbourhoods with their traditions, heritage and the behaviour of its residents (Rabinovich and Shmeleva 1981).

The city of Bukhara stands out as a centre of trade, scholarship, religion and Muslim culture, and as part of the backbone of the ancient trade networks stretching from Northwest China through Central Asia, the Middle East as far west as Rome. In that respect, the term Silk Road, coined in retrospect is grossly misleading, as the concept of a road is usually associated with movement along a line. However, the system under discussion here has a network topology - an arrangement of nodes together with their connecting lines that enabled the exchange of commodities and transmission of knowledge between Asia and Europe.

Bukhara appears as an active node in this network-a node in the sense of a permeable construct of civilization, rather than a closed entity. Situated in the irrigated area between the Amu Darya and Syr Darya rivers, formerly known as Transoxania 
and corresponding roughly to modern-day Uzbekistan, it is usually referred to as a former oasis city. But again, this term is misleading, because the boundaries between the city and the surrounding steppe, or between nomadic and sedentary societies were much more permeable than the rhetoric suggests, as described in Sect. 1.4 on the dichotomy between steppe and sown.

Bukhara thus emerged within a network of mobile relations stretching between the Muslim and the Christian worlds, and as a place whose dynamics were conditioned by different modes of interaction between steppe and sown, nomadic and sedentary societies, material culture and technology. This condition, together with the influx of migrants from other urban centres, largely determined the structure of the city and its neighbourhoods. The concept of 'neighbourhood' is indeed key to understanding the dynamics of Bukhara as discussed in the following.

\subsubsection{Understanding Urban Neighbourhood Principles}

In the European understanding, 'neighbourhood' relates to a number of houses in the city, grouped around a square. The square is surrounded by streets that form the boundary between neighbourhoods. The houses on each side of a street thus belong to different neighbourhoods. This is in contrast to the traditional Central Asian city where a street forms the core of a neighbourhood and unifies the people living on both sides of it, rather than separating them. A neighbourhood may also include small side-walks and cul de sacs branching off from the main street (Sukhareva 1966, 40-41). Neighbourhood boundaries were thus formed by the back walls of houses and their courtyards. Gates sealed the main street; their closure overnight could turn a neighbourhood into a real fortress (Sukhareva 1966, 16-17, 38). Such seclusiveness was both functional and necessary as it protected inhabitants from unrest, menace, robbery and other dangers of the surrounding steppe. This system of defence, through street gates rather than city walls, is typical for many Central Asian cities including Bukhara, and was maintained up to the early twentieth century (Barthold 1966, 157). Hence, it is the courtyards and gates that are the most distinctive features in the neighbourhood of an oriental city, rather than an open square.

With regard to their social composition, neighbourhoods might be inhabited by compact colonies of tribal groups having arrived in Bukhara from one and the same place. Or, they could emerge as a concentration of manufacturer or artisan guilds. Representatives of these guilds formed the majority and lived among other social layers of a local population, such as merchants, clergy, nobility or the descendants of slaves. Frequently, the emergence of local craftsmanship was linked to the arrival of a certain ethnic group.

While Europeans may perceive such cohabitation of the well-to-do and the less privileged as unusual, it worked out much to the advantage of the local population as it neither affected the estate system nor the class privileges. Quite the opposite: wellto-do families profited from the indigent people in their neighbourhood, as they could 
always source from them servants, messengers, porters or tailors at short notice, for casual labour (Sukhareva 1966, 18-19).

Starting from this observation, ethnographers concluded that the study of the entanglements between occupation, ethnic composition and the growth of the city in terms of neighbourhoods and population density must form the departure to their enquiry. The testimonies they based their enquiry on covered the late nineteenth and early twentieth centuries. Although during this period Bukhara had remained under the rule of the Emir, it was kept in the focus of Russian observation until it was besieged by the Red Army in 1920. The task of mapping the city and integrating its Muslim population were thus left to the Soviet government. Hence, the period of the accounts under discussion roughly coincides with the decades between the Russian arrival in Turkestan in the 1860s and 1920.

Outstanding among these testimonies were those compiled in the accounts of Sukhareva who analysed the memoranda of imperial government envoys and previous ethnographic expeditions and eventually completed the abortive ethnographic charts of her predecessors in pre- and post-revolutionary Russia. The reasons for this extended research stretching over more than three generations of scholars were manifold, as were the obstacles they encountered to be outlined in the following periodization.

\subsubsection{Towards a Historical Topography: Knowledge Transfer and Periodization}

The Russian interest in Bukhara, the city the Russians considered its most important economic and political stronghold, had started well before the annexation of Turkestan in the 1860s. Fuelled by "The Great Game", an animation of relations with Bukhara began in the early nineteenth century (Sukhareva 1966, 5).

The term "animation" [оживление] points to a changing pattern of knowledge transfer between Russia's European centre and her Central Asian periphery. Knowledge transfer is used here in the sense of social practice, referring to how people from different cultures interact, what languages they use, and whether their interaction is spontaneous or planned. The periodization suggested below will help to differentiate between these different modes of interaction. Referring to the Russian observations on Bukhara, four stages of knowledge transfer can be identified.

\section{Stage I (1800-1839): Random observations by travellers}

The random observations of merchant-travellers, pilgrims and prisoners at the beginning of the nineteenth century were the point of departure for a more focused knowledge transfer. Important in this respect is the role as a mediator between East and West that Russia had taken on for herself, with the aim of contributing to both popular enlightenment and scholarship in the countries of Western Europe. In 1820, the letter of Jakovlev, a Russian envoy, points out: 
The fact that Russia has, for more than a century, been in touch with Bukhara, Khiva and Tashkent has made foreigners demand from us information about these cities, and rightly so. They require comprehensive knowledge from us separating solid facts from rumours, [...] interesting news about the mores of the lands. This is why we have to do our best to enlighten our fellow citizens about the historical and geographical facts in this part of the world. Who - if not us Russians - would inform European scholarship about present-day Bukhara? (Jakovlev 1824, 50-52)

Stage 2(1840-1867): Regulated observations inspired by the search for new markets

During the second stage, coinciding roughly with the second third of the nineteenth century, Russia needed to develop commerce with Central Asia, and had a particular interest in the trading of silk fabrics, cotton and dyestuffs (A.P. [sic] 1825). That is why this period saw a more active and deliberate transfer of cultural and political knowledge delivered by trained civil servants, military specialists, diplomats and government emissaries. Their observations are documented in a rich body of sources, nearly all of them in Russian. They include newspaper articles issued particularly in the Orenburg region, and essays for periodicals. ${ }^{3}$ Their authors were either Russian professionals or foreigners in Russian service. The few Western publications on Central Asia include the writings of Meiendorff (1820) in French, Eversmann (1823) in German, and Burnes (1842) in English.

\section{Stage 3 (1868-1920): Disciplined observations related to citizen-building}

The third stage - the period following the annexation of Turkestan saw the dispatch of elite emissaries of the tsarist government to the southern periphery, mostly to the cities of Tashkent and Samarkand. These cities lay within the annexed territories, while Bukhara remained under the rule of the Emir. Surrounded as it was, however, by the Governorate General of Turkestan, which constantly expanded, it remained in the focus of Russian politics and influence (Khalid 2000), and became a Russian protectorate in 1873.

During the decades to come, the building of national communities occurred alongside the building of commercial relations with Central Asia. Economic ambitions had to give way to political concerns, of which the policy of citizen-building [гражданственность], i.e. the integration of Russians and non-Russians into a unified community of staunchly Russian citizens, was the principle element.

\section{Stage 4 (after 1920): Systematic ethnographic research as academic enquiry}

A systematic ethnographic enquiry into Bukhara started only under Soviet rule in 1923-24, with a preliminary statistical record on the former Khanate of Bukhara where a census had so far not been conducted. This rough estimate revealed 180,000 residents in Bukhara, compared to an estimated number of 251,800 in 1913-14 (Bukhara v gosudarstvennom khoziaistvennom plane 1923). According to the 1926 census, there were 11,901 homes in Bukhara inhabited by 13,491 families, with

\footnotetext{
${ }^{3}$ Journals include Sovremennik, Otechestvennye Zapiski, Vestnik Evropy, Severnaia Pchela, Aziatskii Vestnik, Sibirskii Vestnik, Aziatskii Zhurnal.
} 
the total number of residents amounting to 46,706 , of which 41,839 were native (Materialy vsesoiuznoi perepisi 1927).

The years 1922-28 saw the restoration of the irrigation system in the region, and the return to the pre-revolutionary policy of exclusively growing cotton on irrigated land. The subsequent period of the first Five-Year plan (1928-32) foresaw the industrialization of the Bukhara region, with a particular focus on cotton production. This included "a speedy inclusion of women into the production process" (Iusupov 1930, 47-49). The plan's directives were chiefly targeted at the female reserve army of labour. Campaigns against religious practice (Kamp 2010), above all against wearing the veil, alternated with the attempted promotion of women into leading positions (Iusupov 1930, 47-49). Literacy campaigns and the provision of medical care were to keep women away from the mullahs.

Thereafter, the mapping of Bukhara was interrupted (Grenet 2013-14, 2015) and only returned to in the late 1930s by the ethnographer, linguist and archeologist Mikhail S. Andreev (1873-1948). The testimonies of elderly Bukharan citizens "as the living carriers of the tradition" (Sukhareva 1966, 19), he suggested, would shed light on their roots, occupations, domestic environment and neighbourhood principles and enable scholars to study the historical topography of a city that had retained many characteristic features from antiquity and medieval times (Sukhareva 1966, 20). However, the field research he had set up in 1940 under the patronage of the Central Asian State University ended prematurely after just one season, as no funds were available to complete the evaluation of their findings (Sukhareva 1966, 20) due to the Great Patriotic War. As a result, the study of Bukhara had to be shelved for a third time, until 1948 when it was restarted following Petrushevskii's call.

\subsection{Ethnographic Enquiry as Systematic Research}

\subsubsection{The Emergence of Sukharava}

As a result of Petrushevskii's call, the material gathered by Andreev and his team was unearthed, and handed over in trust to Olga A. Sukhareva (Fig. 21.1) who turns out to be the first heir to his broadly conceived collective fieldwork (Sukhareva 1966, 19).

As one of the first graduates (1925) from the Turkestan Institute of Oriental Studies, and with a Ph.D. on Islam in Uzbekistan (Sukhareva 1960), she qualifies as a classic representative of the policy of indigenization. The outcomes of her research included a historical study of the cities in the Khanate of Bukhara (Sukhareva 1958) and a comprehensive survey on Bukhara's craft-oriented industries on the basis of a meticulously composed description of the city's distinct neighbourhoods (Sukhareva 1962). Based on those works, she submitted a social history of Bukhara's individual neighbourhoods together with the interaction of their agents (Sukhareva 1966), in which she concentrated on the division of labour across-neighbourhoods and along 


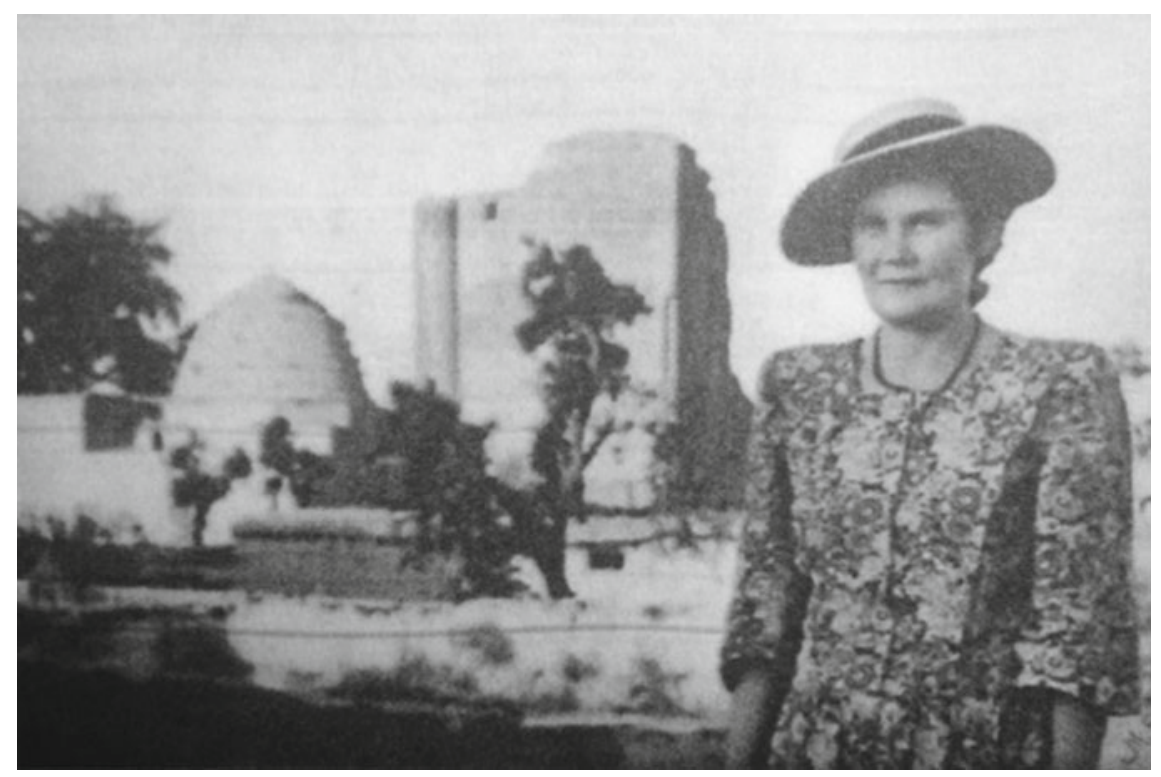

Fig. 21.1 Olga A. Sukhareva, 1903-1983 (Sukhareva 1969, back cover)

the lines of gender in both amateur and professional practice (Sukhareva 1976). In her later works, she linked the historical topography of neighbourhoods to the history and arrival of their residents with a particular focus on the changing perception of women in the oriental city (Sukhareva 1969, 1979). Her achievements were commemorated in a publication launched in 2006 on the occasion of her centenary in 2003 (Abshin and Bushkov 2006). The main source of her findings were the testimonies gained from questionnaires and interviews with Bukharan residents.

As someone who grew up in their midst she spoke their language. Tracing their past enabled her to scrutinize the entanglements between ethnic composition, occupation and the arrival of certain groups in a particular neighbourhood, and thus to expose the growth of the city, both in terms of geographical expansion and population density.

By 1947 when Sukhareva launched her enquiry, the division into small neighbourhoods had been replaced by 16 larger administrative unites (домоуправления). Nevertheless, she could trace individual neighbourhoods on the basis of their architecture (Sukhareva 1976, 11), including dwellings, cemeteries and sanctuaries, together with the ethnic and social composition of its residents: merchants and craftsmen, native and resettled people (Sukhareva 1962, 113). Among them were Turkmens, Arabs, Farsi, both Muslim and Jewish - a colourful mix of people of multiple origins who found themselves living in proximity to each other. Their testimonies, Sukhareva maintained, were the most appropriate, if not the only, avenue to understanding the complexity of urban neighbourhood principles and the heterogeneity of residents whose cosmopolitan heritage forms the underlying theme in all her accounts. 


\subsubsection{Textiles and Bukhara's Cosmopolitan Heritage}

Figure 22.2 shows the distribution of local craftsmanship between Bukhara's different neighbourhoods.

The above legends clearly display the dominance of neighbourhoods inhabited by weavers. What they do not reveal is the dynamics of cross-neighbourhood interaction. Of particular relevance in this respect were the work-related patterns of exchange taking place between the majority Muslim and the minority Jewish communities, who lived in separate neighbourhoods, but allied their talents for the manufacture of complex textiles.

Colourful fabrics held a place of primary significance in Muslim culture while the secrets of their fabrication and dyeing had been in Jewish hands since antiquity. The history of textile weaving and dyeing is thus very much a history of a shared heritage that characterized the cosmopolitan communities of Central Asian cities, particularly Bukhara, both as the stronghold of textile weaving and a centre of Jewish culture in Central Asia.

Today, we associate with 'cosmopolitanism' a mobile society whose people and communities were linked by the 'now' of their social bonds rather than the 'here' of their shared, age-old attachment to a place or tradition. From this follows that mobility would challenge stability. As a former oasis city, Bukhara owed its prosperity, and

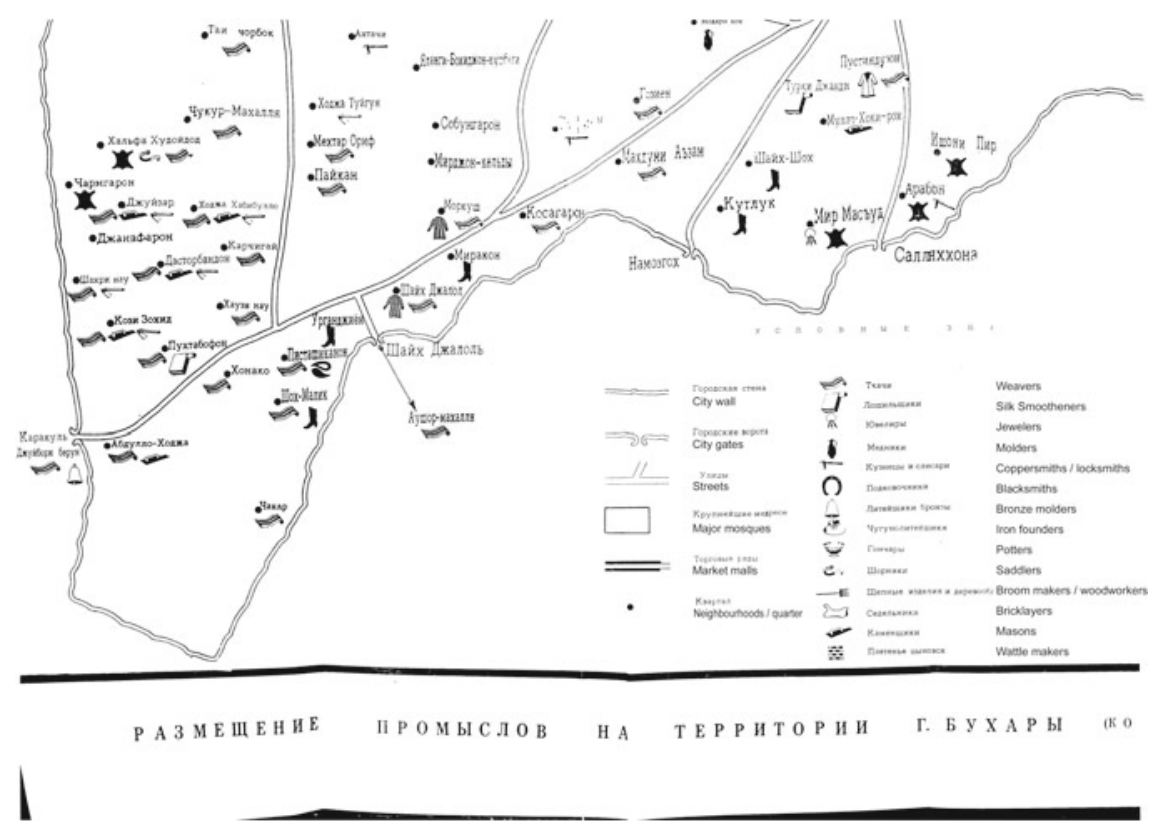

Fig. 21.2 Distribution of local craftsmanship between Bukhara's neighbourhoods (Sukhareva 1962, 16, supplement) 
perhaps its very existence, to the mobility along the Silk Road. Although the Silk Road had been declining in importance for over 400 years when Sukhareva's sources were active, mobility related to trade and textiles (Jacoby 2004)—both intrinsically linked to Muslim and Jewish cultures-was still a dominant factor in professional life after the Russian arrival in Turkestan, which even gave it a boost.

The place of Jewish dyers and textile merchants within the silk trade and their influence upon it were disproportionate to their relatively small numbers. Jewish dressmakers were the first to bring sewing machines to Bukhara to distribute them among the local Muslim population (Sukhareva 1962, 76-77). Moreover, Jews held the monopoly of the dying of silk and cotton yarn and cloths because of their access to rare and precious dyestuffs and techniques (Krauze 1872).

\subsubsection{The Jewish Presence in Bukhara}

The Jewish presence in Central Asia goes back to the times of the Silk Road (Foltz 1998). From the advent of Islam in the seventh century, Jewish traders known as Radanites held a privileged status within the topology of trade networks stretching between Asia and Europe. Their intermediacy allowed them to move freely between Muslim and Christian worlds, and their activities spanned the Carolingian Empire, the Islamic World, the Chinese Empire and the Kingdom of the Khazars (Fischel 1952). In the ninth century, the Persian geographer Ibn Khurdadbih described the Radanites as

... merchants (who) speak Arabic, Persian, Roman (Greek), the language of the Franks, Andalusians, and Slavs. They journey from west to east, partly on land, partly by sea. They transport from the west eunuchs, female and male slaves, silk, castor, marten and other furs, and swords. (Rabinowitz 1948, 51)

As alleged non-believers, Jews were not allowed to marry Muslims. They were excluded from living in the Guzars, ${ }^{4}$ the Muslim neighbourhoods, in order to prevent private interaction with the Muslim population (Loewenthal 1961). Instead, they had been allocated areas at the margins of the city, the so-called Slobodas or Makhallias - terms that the people of Bukhara, Samarkand and other Central Asian cities associate with isolated quarters (Kantor 1929, 9), similar to the Jewish Shtetl in Eastern Europe, where Jews lived separated from other residents.

The close-guarded knowledge of dying methods referred in particular to indigo and kirmiz dyes (Fitz Gibbon and Hale 1997, 182), both greatly appreciated by the Arabs and in the rest of the Islamic world (Butler Greenfield 2005, 19; Kurdian 1941). Russians envoys registered these conditions as early as during the reign of Peter I. In 1724, Florio Beneveni, Russian ambassador to the Emirate of Bukhara from 1718-25, reported to the Russian Ministry of Foreign Affairs:

In this Bukhara land, there is a special type of tree with worms located in a steppe. An expensive dye of kermez, called coushenina [cochineal] in German, can be derived from this

\footnotetext{
${ }^{4}$ Guzar is an Urdu word, it means "a pass, a living, a road".
} 
tree. This dye costs eight roubles a pound in Russia. There is plenty of this dye in Bukhara. The Bukharians [sic], however, do not know the secret of manufacturing this dye. They only collect worms and sell a lot of them to the Jews. And the Jews use those worms to produce the dye. (Beneveni 1986, 85)

Figure 21.3 is an illustration of what Beneveni described in his report.

Nevertheless, the Bukhara government was neither able nor willing to protect the Jewish community against day-to-day harassment, including refined methods of provocation aimed at forced conversion, which represented an imminent danger (Sukhareva 1966, 172). Jews were frequently charged with capital crimes and could only escape death by abjuring their faith (Amitin-Shapiro 1931, 15-36). These con-

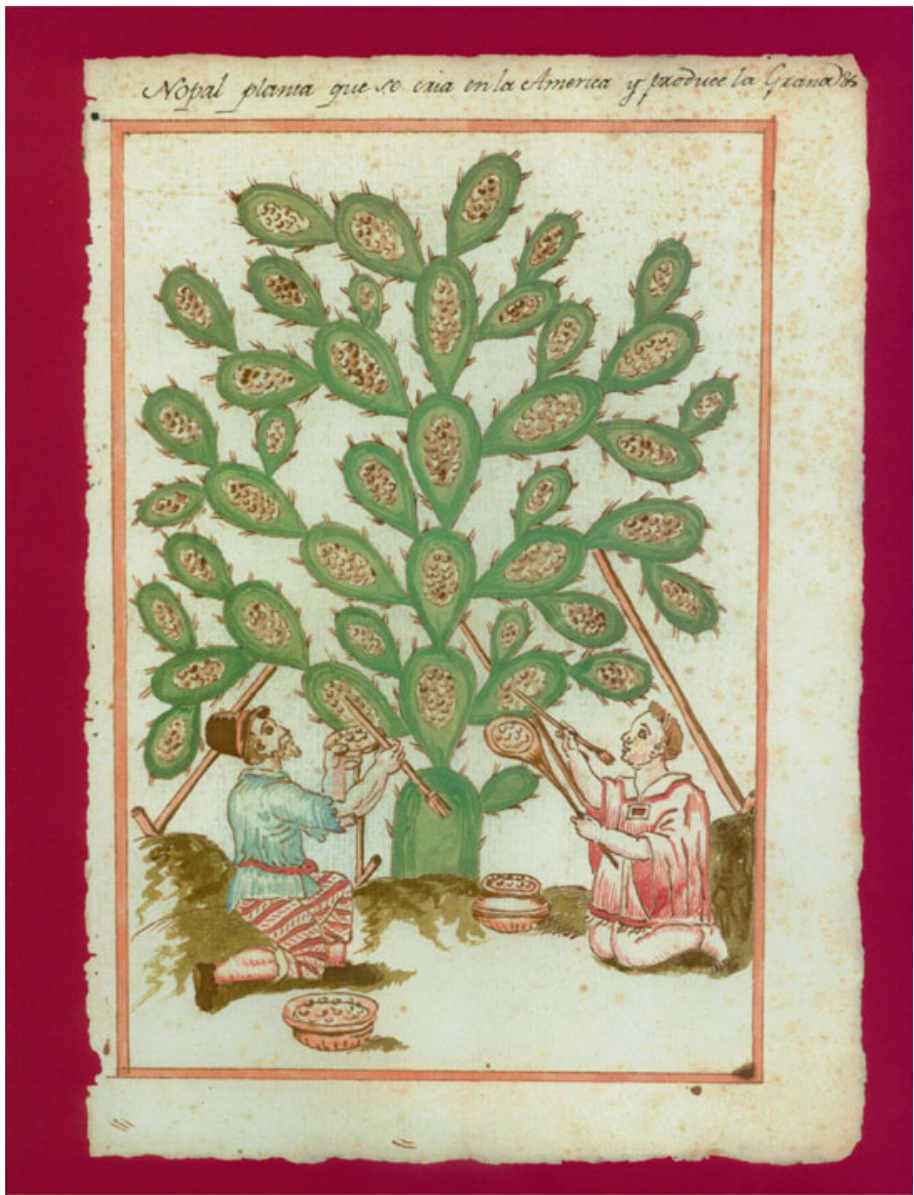

Fig. 21.3 Cochineal parasites feeding on moisture and nutrients from the fruit-bearing prickly pear cactus (genus Opuntid), native to tropical and subtropical Mexico and South America (Phipps 2010) 
verts were known as Muslim-Jews or Chala. ${ }^{5}$ They were forced to leave their quarters and cut off all their family links to live in allocated areas. The Chala communities have been described as the most miserable and tragic of all residents in the Khanate (Babakhanov 1951).

A variety of other crafts existed in Bukhara, many of them in the hands of family workshops (kustari) (Sukhareva 1962, 16-30) that produced fabrics for export to be sold in Samarkand (Grebenky 1873; Sukhareva 1981). However, not all these crafts can be discussed here in detail.

\subsubsection{Mobility Versus Stability: Suzani Expressing a Distinct Sense of Place}

Having shed some light on the male-dominated mobility that was a feature of Bukhara's textile-making and trading, the remainder of this sub-chapter will be devoted to the stability associated with an exclusively female product: suzani-the art of embroidery. As distinctly urban creations, suzani embroideries mirror the female attachment to a place and a tradition of the settled communities in the oasis cities.

Suzani are the most widespread form of household decoration in Bukhara, although the name is applied to all Central Asian embroideries. Suzani means needlework. The term is derived from suzan - the Tajik word for needle (Sukhareva 2013, 5). Suzani-making was the provenance of amateur-artisans working for pleasure rather than profit. According to Sukhareva, it was a typically female way of artistic expression. Women, she argued, were able to reveal their creative abilities more freely than men, whose artistic expressions were generally influenced by their training as craftsmen or in skilled trades and this training would tend to restrict their choice of forms (Sukhareva 1983; Chepelvetskaia and Sukhareva 1991, 75-81).

Suzani embroideries decorated tapestries, bed and bolster covers - the most precious items in the dowry to be used for the nuptial bed (Cootner 1986). They represented fashion and tradition of a place, labour and luxury thereby giving the bride a reassuring memento of her family. Their patterns displayed abstraction from nature, cult or magical meanings that were conveyed by love of ornament, emphatic colour and vigorous line, or from wellbeing, fertility and abundance in a garden, as demonstrated in Fig. 21.4 (Nauchno-issledovatel'skii institute iskusstvoznaniia Uzbekskoi SSR 1955, 89-104).

They could also evoke more dramatic associations with apotropaic images that were understood as protecting oasis inhabitants from the threats in their environment: the surrounding steppe. Some of their images have become widely known, as for example the kalamafur or bodom motifs (Fig. 21.5). Kalamfur refers to the paprika pepper, bodom - to the almond.

Both were thought to afford protection due to their pepperiness and bitterness respectively. They decorated the carpets of vulnerable people, such as pregnant

\footnotetext{
${ }^{5}$ Tajik for 'neither-nor'. Name applied to Bukhara Jews forced to convert to Islam.
} 


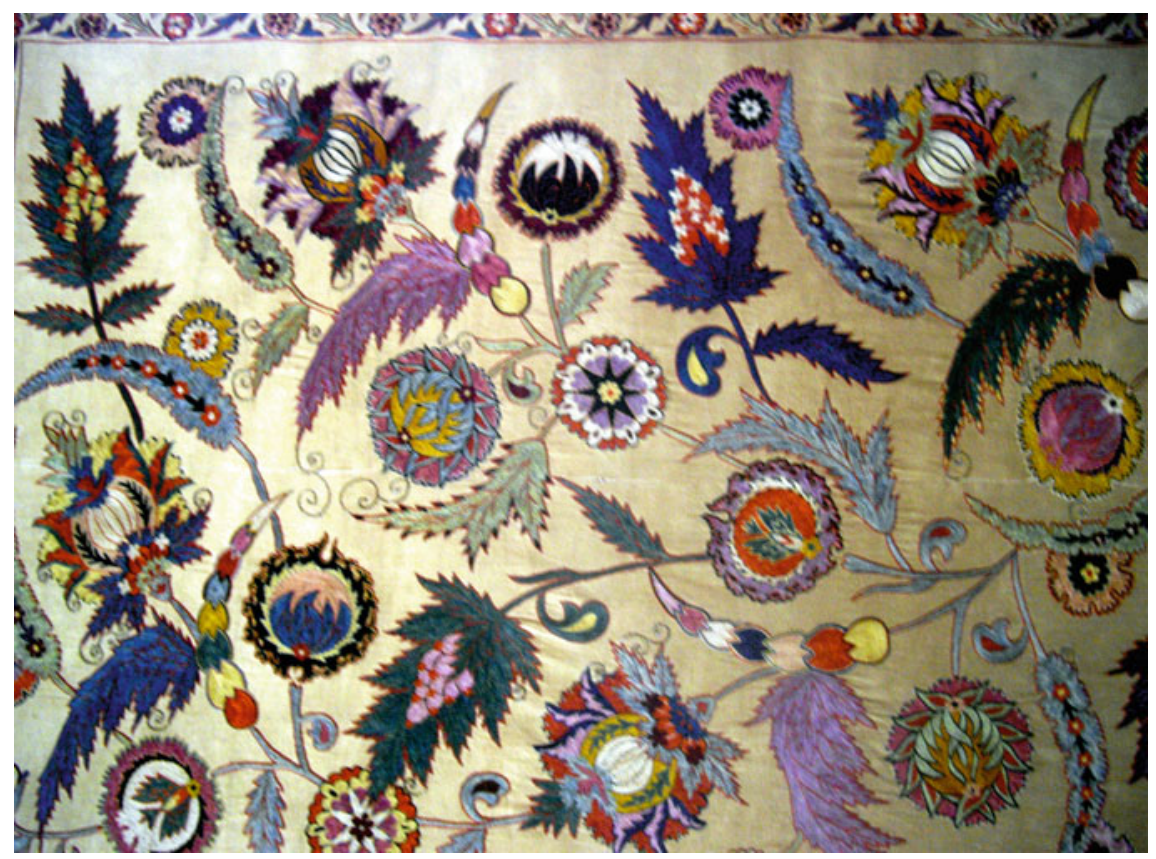

Fig. 21.4 Suzani displaying fertility and abundance in a garden. State Museum of Applied Arts, Tashkent

\section{(a)}

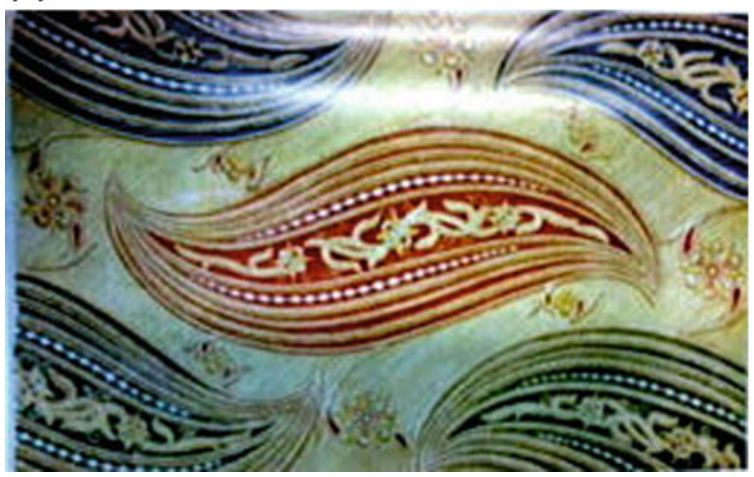

(b)

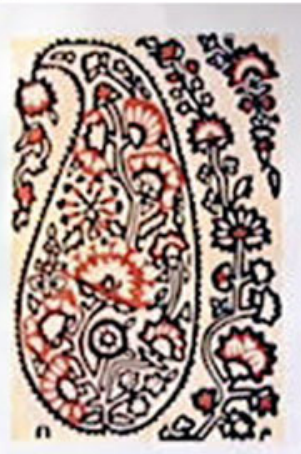

Fig. 21.5 Bodom motif. a is a popular design used on many embroideries (Goncharova 1986, 61). b shows an embroidered bodom motif (Nauchno-issledovatel'skii institute iskusstvoznaniia minesterstva kultury UzSSR 1954, 51)

women or new-born babies. When the pattern became commercialised it travelled to Norwich for the factory production of shawls, and then further to Paisley, where the eponymous pattern was made (Karpinski 1963). 


\subsubsection{Messengers from an Ancient Past}

Suzani belong to the artistic creations of the settled communities in the oasis cities, rather than of the nomadic tribes. While their flowering period falls into the years 1850-80 (Chepelvetskaia and Sukhareva 1991, 27), the tradition of their creators had far more ancient origins. These origins should be sought in the sedentary cultures of the ancient centers of Sogdiana (Liu 2010, 67). "Sogdiana" is the earliest name of the country between the rivers Amu Darya and Syr Darya (Sukhareva 2013, 11).

Among these settled communities, a sense of ethnic identity remained undeveloped until well into the Modern Age. This is reflected in the suzani, in which no ethnical peculiarities can be traced, as they emerged as the art of compact settlements, with centres of production crystallizing in Bukhara and Samarkand, besides Tashkent and Shakhrisyabz. In the steppe regions with the ancient irrigated farming outside Bukhara, there were no suzani-type embroideries (Sukhareva 2013, 11).

Suzani patterns could express the energy of spring in the steppe oasis. Or they could display a more immediate concern of the women who made them: the longing for rest and coolness provided by a shaded garden. The general theme is 'Water and Shade' (Taube 1994, 17-18), not surprisingly since Islam spread in a hot and arid climate. Plants implied water, and water was associated with healing, beauty and wealth.

Gardens were important for leisure, for supplying fruit and vegetables to the family, and for their symbolism, as an earthly representation of paradise (Franses 2000, 25-26). They meant an oasis of freedom for urban women; inside their walls, women could enjoy the beauty of nature in the company of friends and family unencumbered by heavy veils. As the most important outward symbol of the wealth of a family, they were enlarged at every possible opportunity. Hence, no discussion of urban life in Bukhara could be complete without mentioning the magnificent gardens in the city's western part (Sukhareva 1966, 32-33).

Suzani came to belong to the universal style of Islamic art, with the infinite repeating and enlargement of patterns. Their embroideries are not concerned with details but rather with the abstract qualities of nature (Franses 2001) and motifs of the universe, both astral and vegetal (Fig. 21.6). ${ }^{6}$

Stitched on a background of cotton or silk, they dissolve into huge central medallions, rhombuses and concentric circles, representing sun and stars, stylized flowers and petals, continuing branches and garden segments suggesting a human desire to live in harmony with the natural environment and the universe.

Given the nature of the dowry gift itself, many of the weavings bore symbols of fertility, such as pomegranates (Fig. 21.7). While the function of suzani, and their motifs have evolved like a living language since ancient times, they could also take on new meanings with new times and generations. Their use could even change during the lifetimes of the family members who made them.

\footnotetext{
${ }^{6}$ The claim that the representation of living forms in art is forbidden by the Koran can be neglected here, as it is not applicable to textiles. Unlike sculpture and painting, textiles have always been neutral ground for images.
} 


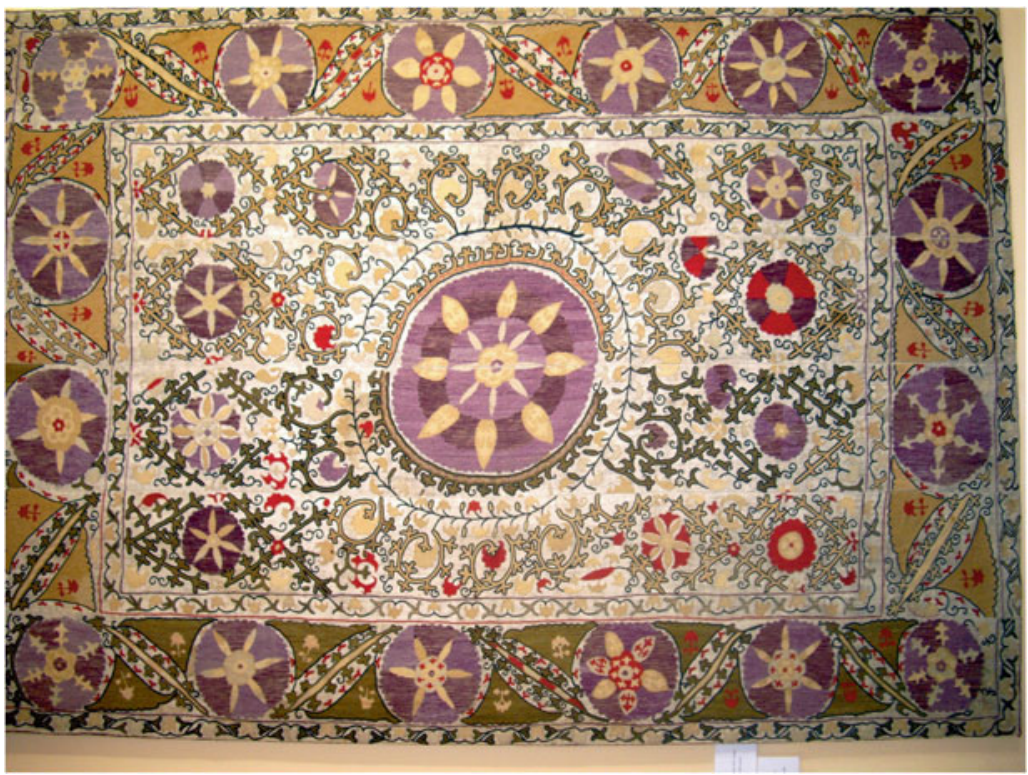

Fig. 21.6 Astral and vegetal motifs stitched on a suzani from mid-19th-century Bukhara (cotton). Samarkand Museum fort the History and Art of the Uzbek People

Fig. 21.7 Stylized

pomegranate (Goncharova 1986, 68)

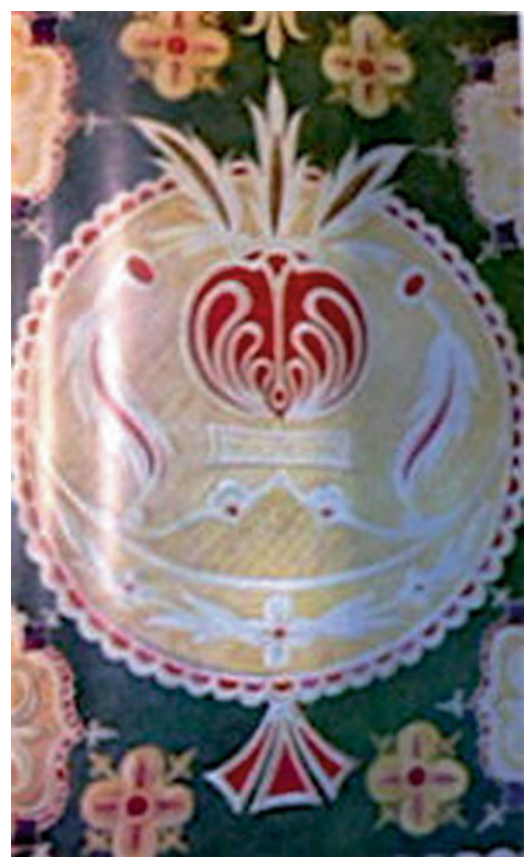


(a)

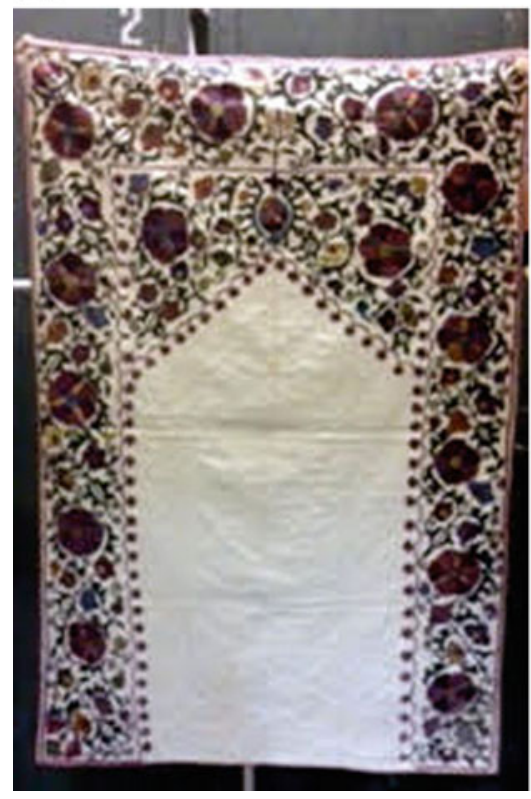

(b)

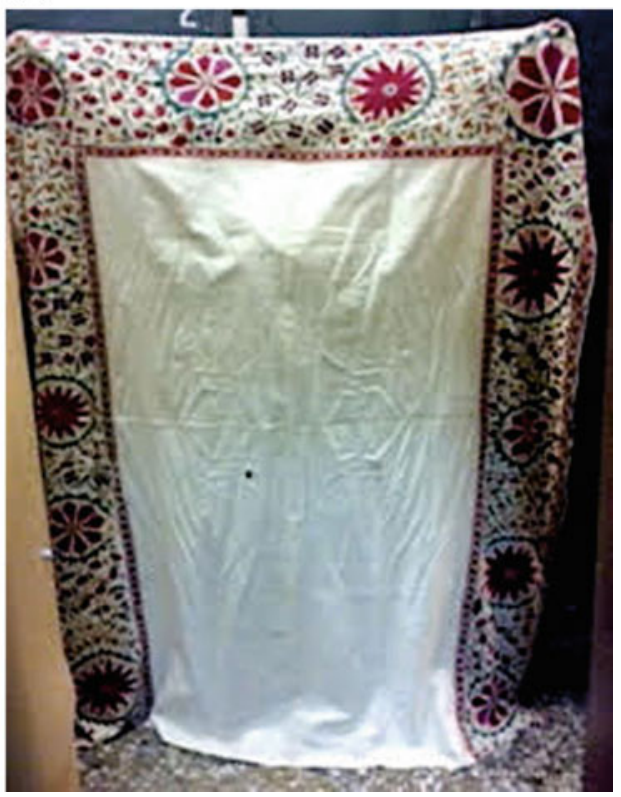

Fig. 21.8 a shows a prayer mat (dzhai namaz) made in Bukhara around 1850, and b shows a bedspread (dzhai push), literally: place cover and part of a dowry suit. According to Sukhareva, it was made in Bukhara between 1850 and 1880. The $\Pi$-shape of the Mihrab is well recognizable. Both pieces belong to the archival collection of the Russian Museum of Ethnography, St. Petersburg: a: no. 58-133; b: no. 58-153. The explanations have been provided by O. A. Sukharva on 24/25 May 1956, written down by A. S. Morozova and M. B. Sazanova

Further functions of suzani included the decoration of a niche in the wall where bedding was stored during daytime. They could decorate a table or bread cloth, a sandal quilt (Sandali-push) $)^{7}$ or a prayer mat (Namazlyk—or Dzhai-namaz). The shape of a prayer mat invites embroidered embellishments in the form of a п-shape imitating the Russian letter п (p), i.e. featuring on just three sides of a rectangular mat. In many prayer mats, they dissolve into a bold arch motif-the two-dimensional representations of the Mihrab (михраб), thereby recreating an ornament typical for Muslim architecture (Fig. 21.8a).

The Mihrab imitated a niche in the wall of a mosque indicating the direction of Mecca, the direction that a person should face when praying. With regard to Bukhara, there is a peculiarity about the Mihrab, as it embellished not only prayer mats, but also bed covers (Dzhai-push) (Fig. 21.8b).

This Mihrab shaped embroidery on a bedspread is exceptional, because no Mihrab shapes graced the bed covers in the other cities (Sukhareva 1956), which suggests

\footnotetext{
${ }^{7}$ A small wooden table placed over a charcoal brazier set in a hole in the kitchen floor with covering quilts channelling the heat to the legs of people sitting around it. During the short, but cold winters families gathered around the sandal and slept near them (Bacon 1966, 61).
} 
that the Muslim tradition was deeper rooted among Bukharans than among the settled communities of Sakhrizabs, Samarkand and Tashkent.

\subsection{Conclusion}

What is the relevance of the ethnographic accounts on Bukhara under discussion in this chapter for our understanding of the interrelationship between environmental factors and socio-cultural changes in the area around the ancient Silk Road? What role might they play in today's renewed discussion on Eurasian integration? And to what extent can they serve as a guideline to global intellectual interaction?

Firstly, the ethnographic accounts expose an approach that distinguished between the domestic lifestyle of the settled people in the oasis cities and the nomadic lifestyle in areas where severer climatic conditions made civilization more fragile. The accounts discussed here unravel the various layers of Bukhara's cosmopolitan heritage. In their way of juxtaposing mobility and stability, they reveal that this heritage was conditioned by the city's geopolitical situation through time, a shared Muslim-Jewish history of textile weaving and dyeing, and the division of labour along lines of gender linked to amateur and professional practice.

Secondly, said accounts relied on testimonies, reported observations and scholarship. In their confrontation of lived knowledge conveyed linearly by generations of residents, with the systemized knowledge of academic enquiry mined vertically to deepen insights, the transcultural perspective of the local agents who assembled them turned out to be a crucial factor.

Thirdly, these accounts of human agency appear as discursive events. The way they were assembled and presented demonstrates that knowledge was acquired as an act of cooperation, in which the will to understand and to communicate was considered a prerequisite for dialogue, appreciation, academic reorientation and joint action.

The momentum of such knowledge acquisition and transfer was related to the speed and permanence of its flow via the continental bridge. This points to the notion of soil and its significance in the school of Eurasianism; it is still relevant to our understanding of knowledge flowing between Asia and Europe, and hence for the Eurasian integration project as an intensified process of cultural interaction between Asia and Europe. Advancing this project implies a change of perspective, and a flexible approach that allows agents to negotiate between soft and hard skills, cultural theory and local practice, between the history of ideas and the history of geographical space. This balancing act is as significant today as it was during the times of the ancient Silk Road.

Acknowledgements My research for this article was enabled by a visiting fellowship provided during the academic year 2014/15 by the cluster of excellence "Asia and Europe in a Global Context" at the University of Heidelberg. I am also grateful to the University of Portsmouth for sabbatical leave enabling me to complete the work. 


\section{References}

Abshin, S. N., \& Bushkov, V. I. (2006). Sredneaziatskii etnograficheskii sbornik. K 100-letiiu so dnia rozhdeniia Olgi Aleksandrovny Sukharavoi [Collected works on ethnographic research in Central Asia. On the occasion of the 100th anniversary of O. A. Sukhareva. Vypusk V.]. Moskva: Nauka.

Amitin-Shapiro, Z. L. (1931). Ocherki pravogo byta sredne-aziatskikh evreev [Remarks on legal matters of Jews in Central Asia]. Tashkent, Samarkand: Uzbek State Publishing House.

Babakhanov, I. M. (1951). K voprosu o proiskhozhdenii gruppy evreev-musul'man v Bukhare. Sovetskaia Etnografiia, 3, 162-163.

Bacon, E. E. (1966). Central Asians under Russian rule. A study in culture change. Ithaka, New York: Cornell University Press.

Barthold, V. V. (1927). Istoriia kul'turnoi zhizni Turkestana [A cultural history of Turkestan]. Leningrad.

Barthold, V. V. (1966). Sochineniia [Works] (Vol. VI, p. 157). Moskva.

Bassin, M. (1991). Russia between Europe and Asia: The ideological construction of geographical space. Slavic Review, 50(1), 1-17.

Beneveni, F. (1986). Reports and letters (1724). In N. A. Halfin (Ed.), Poslannik Petra i na Vostoke [Peter's the great envoy to the East]. Moskva: Nauka.

Biulleten Sredne-Aziatskogo Gosudarstvennogo Universiteta [Bulletin of the Central Asian State University]. (1924). 7, 45.

Brower, D. (1997). Islam and ethnicity. Russian Colonial Policy in Turkestan. In D. R. Brower \& E. J. Lazzerini (Eds.), Russia's orient. Imperial borderlands and peoples, 1700-1917 (pp. 115-135). Bloomington: Indiana University Press.

Bukhara v gosudarstvennom khoziaistvennom plane na 1923 i 1924 gg. [Bukhara in the state economic plan of the years 1923 and 24]. (1923). Staraia Bukhara, 54, table 10.

Burnes, A. (1842). Travels into Bokhara [sic]. London: John Murray.

Butler Greenfield, A. (2005). A perfect red. Empire, espionage and the quest for the colour of desire. London: Harper College Publisher.

Chepelvetskaia, G. L., \& Sukhareva, O. A. (1991). Susani Usbekistans. Ein Beitrag zur Technik, Ornamentik und Symbolik der usbekischen Seidenstickerei. Hamburg: Reinhold Schletzer Verlag.

Cootner, C. M. (1986). Gardens of paradise, history and technique. Hali. The International Journal of Oriental Carpets and Textiles, 30, 46-48.

Eversmann, E. (1823). Reise von Orenburg nach Buchara. Berlin: Verlag von E.H.G. Christiani.

Fischel, W. J. (1952). The Jewish merchants, called radanites. Jewish Quarterly Review (New Series), 42, 321-325.

Fitz Gibbon, K., \& Hale, A. (1997). Central Asian Jews and the silk trade. In K. F. Gibbon \& A. Hale (Eds.), Splendid silks of Central Asian Ikat (pp. 172-192). London: The Guido Goldman Collection.

Foltz, R. (1998). Judaism and the silk route. The History Teacher, 32(1), 9-16.

Foltz, R. C. (1999). Religions of the silk road. Overland trade and cultural exchange from antiquity to the fifteenth century. New York: St. Martin's Press.

Franses, M. (2000). The great embroideries of Bukhara. London: Textile Art Publications.

Franses, M. (2001). Flower power. Hali, 115, 93-98.

Goncharova, P. A. (1986). Zolotoshveinoe iskusstvo Bukhary [The art of gold embroidery in Bukhara]. Tashkent: Izdatel'stvo literatury i iskusstva im. Gafura Guliama.

Grebenky, N. F. (1873). Remeslennaja deiatelnost' tadzhikov Zeravshanskogo okruga [Tajik artisan activities in the Zeravshansky region]. Turkestanskii Sbornik (St. Petersburg), 52, 511-514.

Grenet, F. (2013-14). Histoire et cultures de l'Asie central préislamique. Annuaire du Collège de France. Résumés.

Grenet, F. (2015, November 18). Personal communication and discussion of paper at the Fourth International SEECHAC Colloquium on "Religious Revivals and Artistic Renaissance in Central Asia and the Himalayan Region-Past and Present", University of Heidelberg, November 16-18. 
Grousset, R. (1970). The empire of the steppes (p. ix). New Brunswick, New York: Rugers University Press.

Halperin, C. J. (1983). George Vernadsky, Eurasianism, the Mongols, and Russia. Slavic Review, 43(3), 477-493.

Hirsch, F. (2005). Empire of nations: Ethnographic knowledge and the making of the Soviet Union. Ithaka: Cornel University Press.

Huhn, U. (2016). Die Wiedergeburt der Ethnologie aus dem Geist des Atheismus. Zur Erforschung des „zeitgenössischen Sektierertums“ im Rahmen von Chruščevs antireligiöser Kampagne. Jahrbücher für Geschichte Osteuropas, 64(2), 260-298.

Iusupov, U. (1930). Vystuplenie na VII. Sredneaziatskom kraevom soveshchanii po rabote sredi zhenshchin sostoialas, 26 dekabria 1929 goda-2 ianvaria 1930 goda [Speech given at the 7th Central Asian advisory meeting on activities to be carried out among women, 26 December 1929 to 2 January 1930]. Orden trudovogo znamenii institut istorii partii pri TsK KP Uzbekistana Filial instituta marksizma-leninizma pri TsK KPSS [Launched by the historical institute of the central ctee of the communist party of Uzbekistan - branch of the institute of Marxism-Leninism at the central committee of the CPSU. Izbrannye Trudy. I [Selected works] Tashkent: Akademiia Nauk Uzbekskoi SSR.

Jacoby, D. (2004). Silk economics and cross-cultural artistic interaction: Byzantium, the Muslim world, and the Christian west. Dumbarton Oaks Papers, 58, 197-240.

Jakobovsky, A. I. (1951). Glavnye voprosy izucheniia istorii goroda Srednei Azii [Main aspects for the historical study of the historical city]. Trudy Tadzh. Filiala SSSR (Dushanbe), 29(3/4).

Jakovlev, P. (1824). Zamechaniia na fakty. Nekotorye svedeniia o Bukhare, napechatanyi v "Otechestvennykh Zapiskakh" 1821 g. Sibirskii Vestnik, St. Petersburg.

Jersild, A. L. (1997). From savagery to citizenship: Caucasian Mountaineers and Muslims in the Russian Empire. In D. R. Brower \& E. J. Lazzerini (Eds.), Russia's orient. Imperial borderlands and peoples, 1700-1917. Bloomington: Indiana University Press.

Kamp, M. (2010). Where did the Mullahs go? Oral histories from rural Uzbekistan. Die Welt des Islams, 50, 503-531.

Kantor, L. M. (1929). Tuzemnye evrei v Uzbekistane [Indigenous Jews of Uzbekistan]. Tashkent: Uzbek State Publishing House.

Karpinski, C. (1963). Kashmir to Paisley. The Metropolitan Museum of Art Bulletin (New Series), 22(3), 116-123.

Khalid, A. (2000). Society and politics in Bukhara, 1868-1920. Central Asian Survey, 19(3/4), 367-396.

Khalid, A. (2007). Islam after communism: Religion and politics in Central Asia. Berkeley: University of California Press.

Khalid, A. (2015). Making Uzbekistan. Nation, empire, and revolution in the early USSR (p. 270). London: Cornell University Press.

Krauze, I. (1872). Zametki o meditsinskikh i nekotorykh rasteniiakh v Srednei Azii [Remarks on medical and other plants in Central Asia]. Russkii Turkestan. Stati po etnografii, tekhnike, selskomu khoziaistva i estestvennoi istorii [Russian Turkestan. Articles on ethnography, technology, agriculture and natural history], Vypusk 2 (pp. 262-273). Moskva: Universitetskaia Typografiia.

Kurdian, H. (1941). Kirmiz. Journal of the American Oriental Society, 61(2), 105-107.

Laruelle, M. (2007). The orient in Russian thought at the turn of the century. In D. Shlapentokh (Ed.), Russia between East and West. Scholarly debates on eurasianism (pp. 9-37). Leiden, Boston: Brill.

Liu, X. (2010). The silk road in world history. Oxford: Oxford University Press.

Loewenthal, R. (1961). Les Juifs de Boukhara. Cahiers du Monde Russes et Soviétique, 2(1), $104-108$.

Materialy vsesoiuznoi perepisi 1926 goda [Data on the comprehensive Soviet census of the year 1926]. (1927). Samarkand, 41.

Meiendorff, C. (1840). Journey of the Russian mission from Orenburg to Bokhara [sic]. (C. Monteith, Trans.). Madras Engineers, Madras: Spectator press (first published in 1820). 
Nauchno-issledovatel'skii institut iskusstvoznaniia minesterstva kultury UzSSR [Scientific research institute for art historical studies at the ministry of culture of the UzSSR]. (1954). Narodnoe dekorativnoe iskusstvo Sovetskogo Uzbekistana [The decorative art of the people in Soviet Uzbekistan]. Tashkent: Izdatel'stvo akademii nauk Uzbekskoi SSR.

Nauchno-issledovatel'skii institute iskusstvoznaniia Uzbekskoi SSR. (1955). Narodnoe dekorativnoe iskusstvo sovetskogo Uzbekistana [The decorative art of the people in Soviet Uzbekistan]. Moskva: State Publishing House.

P. [sic]. (1825). Noveishee opisanie Velikoi Bukhari. Zhiteli Bukhari, ikh promyshlennost' i torgovlia [Latest description of Greater Bukhara. The people of Bukhara, their trades and industries]. Aziatskii Vestnik (Izdatel'stvo Nauka i Iskusstva), 304-317.

Petrushevskii, I. P. (1948). Gorodskaia znat v gosudarstve Khulaguidov. Sovetskoe Vostokovedenie. V. Moskva.

Phipps, E. (2010). Cochineal red: The art history of a color. The Metropolitan Museum of Art Bulletin (New Series), 67(3), 4-48.

Rabinovich, M. G., \& Shmeleva, M. N. (1981). Ketnograficheskomu izucheniiu goroda. Programma etnograficheskogo izucheniia gorodov [About the ethnographic study of cities. Programme of ethnographic research about the city]. Sovetskaia Etnografiia, 3, 23-44.

Rabinowitz, L. (1948). Jewish merchant adventurers: A study of the radanites. London: Goldston.

Riasanovsky, N. V. (1967). The emergence of Eurasianism. California Slavic Studies, 4, 39-72.

Sartori, P. (2016). Visions of justice: Shar'̀' a and cultural change in Russian Central Asia. Leiden: Brill.

Savitsky, N. S., Trubetskoi, N. S., Suvchinsky, P. P., \& Florovsky, G. V. (1921). Iskhod k vostoku (Exodus to the East). Sofia: Rossiisko-bolgarskoe knigoizdatel'stvo.

Schreider, A. (1921). Unsere Aufgaben [mission statement]. Znamia - Standarte. Zeitschrift für Literatur, Politik und Kunst, 1,1 .

Schuyler, E. (1966). Turkistan [sic]. Notes of a journey in Russian Turkistan, Kokand, Bukhara and Kuldja bye (edited with an introduction by G. Wheeler) (p. XIII). London: Routledge \& Kegan Paul.

Shishkin, V. A. (1936). Arkhitekturnye pamiatniki Bukhary [Architectural monuments of Bukhara]. Tashkent.

Shishkin, V. A. (1943). Goroda Uzbekistana [The cities of Uzbekistan]. Tashkent.

Sirazhdinov, S. (1970). Taschkentskii Gosudarstvenyi Universitet im. V.I. Lenina [Tashkent State University, V.I. Lenin]. Ocherki [Remarks] (Tashkent: Gosudarstvennoe izdatel'stvo), 34-35(44), 310-312.

Sovremennyi kishlak Srednei Azii [The Modern Kishlak of Central Asia]. (1926). Sotsialnoekonomicheskii ocherk, IV Vabkentskaia volost', Tashkent.

Stronski, P. (2011). Forging a Soviet City, 1930-1966. Pittsburgh: University of Pittsburgh Press.

Sukhareva, O. A. (1956). Information provided on item 58-153 of the suzani collection in the Russian Museum of Ethnography, St. Petersburg, on 24 and 25 May, written down by A.S. Morozova \& M.B. Sazanova.

Sukhareva, O. A. (1958). K istorii gorodov Bukharskogo khanstva (Istoricheskie ocherki) [The historical cities in the Khanate of Bukhara. Historical essays]. Tashkent: Izdatel'stvo Akademii Nauk Uzbekskoi SSR.

Sukharev, O. A. (1960). Islam v Uzbekistane [Islam in Uzbekistan]. Tashkent: Izdatel'stvo Akademii Nauk Uzbekskoi SSR.

Sukhareva, O. A. (1962). Posdnefeodal'nyi gorod Bukhara kontsa 19-nachala 20 veka. Remeslennaia promyshlennost' [Bukhara-The post-feudal city during the late 19th and early 20th centuries. Artisan-industries]. Tashkent: Izdatel'stvo Akademiia Nauk Uzbekskoi SSR, Institut Istorii i Arkheologii.

Sukhareva, O. A. (1966). Bukhara XIX - nachalo XX v. Posdnefeodal'ny gorod i ego naselenie [Bukhara during the 19th and early 20th centuries. The post-feudal city and its population]. Moskva: Izdatel'stvo Nauka. 
Sukhareva, O. A. (1969). Suzani. Sredneaziatskaia dekorativnaia vyshevka [Suzani. Central Asian decorative embroideries] Moskva: Izdatel'skaia firma 'Vostochnaia literatura" RAN (an English translation appeared in 2011 under the title: Suzani. Central Asian decorative embroidery. International Institute for Central Asian Studies, Samarkand State United Historical-Architectural and Art Museum. Tashkent: publisher unknown).

Sukhareva, A. O. (1976). Kvartal'naia obshchina posdnefeodal'nogo goroda Bukhary (v sviazi $s$ istoriei kvartalov) [Understanding Urban Neighbourhood Principles in Post-Feudal Bukhara (Linked to the History of Neighbourhoods)]. Moskva: Izdatel'stvo Nauka.

Sukhareva, O. A. (1979). Kostium narodov Srednei Azii.Istoriko-etnograficheskie ocherki [The costume of the peoples in Central Asia. Essays on history and ethnography]. Akademiia Nauk SSSR, Institut Etnografii im. N.N. Miklukho-Maklaia. Moskva: Izdatel'stvo Nauka.

Sukhareva, A. O. (1981). O tkatskikh remeslakh v Samarkande [On the weaving industries of Samarqand]. In Akademiia Nauk Tadzh. SSR, Institut istorii im. A. Donisha (Ed.), Istoriia $i$ etnografiia narodov Srednei Azii (pp. 25-37). Dushanbe: Donish.

Sukhareva, O. A. (1983). Ornament dekorativnykh vyshivok i ego sviaz's narodnymi predstavleniiami i verovaniiami [Folklore, imaginations and beliefs in the ornaments of decorative embroideries]. Sovetskaia Etnografiia (Moskva), 6, 67-79.

Sukhareva, O. A. (2013). Suzani. Central Asian decorative embroidery. Tashkent: International Institute for Central Asian Studies, Samarkand State United Historical-Architectural and Art Museum.

Taube, J. (1994). Suzani. A textile art from Central Asia. With an introduction and text to the collection by Ignazio Vok. Munich: Edition Vok.

Tolz, V. (2005). Orientalism, nationalism and ethnic diversity in late Imperial Russia. The Historical Journal, 48(1), 127-150.

Tolz, V. (2011). Russia's own orient. The politics of identity and oriental studies in the late Imperial and Early Soviet periods. Oxford: Oxford University Press.

Umniakov, I. I. (1923). K voprosu ob istoricheskoi topografii Bukhary [About the historical topography of Bukhara]. Sbornik Turkestanskogo Vostochnogo instituta v chest A. E. Shmidta. Tashkent.

Yaroshevski, D. (1997). Empire and citizenship. In D. R. Brower \& E. J. Lazzerini (Eds.), Russia's orient. Imperial borderlands and peoples, 1700-1917 (pp. 61, 65-72). Bloomington: Indiana University Press.

Open Access This chapter is licensed under the terms of the Creative Commons Attribution 4.0 International License (http://creativecommons.org/licenses/by/4.0/), which permits use, sharing, adaptation, distribution and reproduction in any medium or format, as long as you give appropriate credit to the original author(s) and the source, provide a link to the Creative Commons license and indicate if changes were made.

The images or other third party material in this chapter are included in the chapter's Creative Commons license, unless indicated otherwise in a credit line to the material. If material is not included in the chapter's Creative Commons license and your intended use is not permitted by statutory regulation or exceeds the permitted use, you will need to obtain permission directly from the copyright holder. 